\title{
Pemberdayaan Anak-Anak Panti Asuhan melalui Edukasi dan Pelatihan Pembuatan Sabun Cair Antiseptik
}

\author{
Meilani Jayanti $^{1 *}$, Surya Sumantri ${ }^{1}$, Imam Jayanto ${ }^{1}$, Jainer Pasca Siampa ${ }^{1}$ \\ ${ }^{1}$ Program Studi Farmasi, Fakultas Matematika Dan Ilmu Pengetahuan Alam Universitas Sam Ratulangi \\ *Penulis Korespondensi, Meilani Jayanti Program Studi Farmasi FMIPA Universitas Sam Ratulangi Manado 95115. \\ Email: meilanijayanti@unsrat.ac.id
}

\begin{abstract}
ABSTRAK
Panti asuhan yang merupakan lembaga sosial nirlaba, secara tidak langsung ikut mengalami dampak yang diakibatkan oleh adanya pandemi COVID-19. Banyak donatur yang mulai membatasi sumbangan yang diberikan ke panti-panti asuhan. Sedangkan, panti asuhan masih membutuhkan banyak biaya untuk keberlangsungan operasionalnya. Oleh karena itu, untuk membantu panti asuhan menjadi lebih mandiri dalam perekonomiannya, maka tim pengabdian kepada masyarakat dari Fakultas Matematika dan Ilmu Pengetahuan Alam Universitas Sam Ratulangi melaksanakan edukasi dan pelatihan pembuatan sabun cair antiseptik yang juga menjadi upaya pencegahan penularan COVID-19. Kegiatan ini dimulai dari tahap koordinasi, persiapan kegiatan, pelaksanaan penyuluhan, pelatihan pembuatan sabun cair antiseptik, serta evaluasi. Kegiatan ini memberikan pengetahuan dan keterampilan kepada anak-anak di panti asuhan mengenai sabun cair antiseptik dengan pemberian edukasi tentang sabun, pelatihan pembuatan sabun cair, pengemasan hingga pemasaran, serta praktek cara cuci tangan yang benar. Pengetahuan dan keterampilan tersebut diharapkan dapat terus diimplementasikan oleh panti asuhan, sehingga dapat meningkatkan produktivitas ekonomi panti asuhan. Selain itu, produk sabun yang dihasilkan dapat dimanfaatkan dalam lingkungan panti asuhan sebagai upaya pencegahan penularan COVID-19.
\end{abstract}

Kata Kunci: Panti Asuhan; Antiseptik; Produktivitas; COVID-19

\section{ABSTRACT}

The orphanage, which is a non-profit social institution, has indirectly been affected by the COVID19 pandemic. Many donors have begun to limit the donations given to orphanages. Meanwhile, the orphanage still requires more money for its operational continuity. Therefore, to help orphanages become more independent in their economy, the community service team from the Faculty of Mathematics and Natural Sciences, Sam Ratulangi University, conducted education and training on making antiseptic liquid soap which is also an effort to prevent the transmission of COVID-19. This activity starts from the coordination stage, preparation of activities, health education, training on making antiseptic liquid soap, and evaluation. This activity delivers knowledge and skills to children in orphanages about antiseptic liquid soap by providing knowledge about soap, training on soap making, packaging to marketing, and training on washing hands properly. The knowledge and skills can be implemented continuously by the orphanage so it can increase their economic productivity. In addition, the soap products their produce can be an effort to prevent the transmission of COVID-19.

Keywords: The orphanage; Antiseptic; Productivity; COVID-19

\section{PENDAHULUAN}

\section{Analisis Situasi}

Situasi pandemi COVID-19 di Indonesia menunjukkan tingkat kematian yang cukup tinggi selama hampir 2 tahun terakhir (Satgas Penanganan COVID-19). World Health Organization (WHO) mengumumkan bahwa penyebab COVID-19 yaitu adanya infeksi virus pada saluran pernafasan oleh Severe Acute Respiratory Illness Coronavirus-2 (SARS-CoV2). Infeksi SARS-CoV-2 menunjukkan gejala yang berbeda pada tiap pasien. Kebanyakan pasien menunjukkan gejala berupa demam, batuk, kelelahan dan kehilangan indra perasa atau 
JPAI

Jurnal Perempuan dan Anak Indonesia

penciuman. Selain itu, cukup banyak juga pasien yang menunjukkan gejala berat, seperti sesak nafas atau kesulitan bernafas hingga dapat berakhir dengan kematian.

Berdasarkan hal tersebut, Pemerintah Indonesia melalui Kementerian Kesehatan menyusun berbagai pedoman untuk dapat diterapkan di semua fasilitas pelayanan kesehatan dan masyarakat sebagai upaya pencegahan dan pengendalian penyebaran COVID-19. Pedoman tersebut berisi langkah-langkah pencegahan yang paling efektif untuk diterapkan di masyarakat, diantaranya mencuci tangan dengan sabun (Z.A., Safrizal, dkk., 2020). Tangan menjadi salah satu media bagi virus SARS-CoV-2 untuk berpindah ke tubuh manusia. Hal ini dikarenakan tangan merupakan anggota tubuh yang paling sering digunakan untuk melakukan berbagai aktivitas, sehingga tanpa disadari dapat dengan mudah terkontaminasi droplet dari pasien COVID-19 yang kemudian tangan tersebut digunakan menyentuh hidung, mulut atau mata. Oleh karena itu, mencuci tangan dengan menggunakan sabun menjadi salah satu langkah paling penting dalam pencegahan infeksi COVID-19 (Anonim, 2020).

Sabun merupakan salah satu bahan pembersih yang termasuk dalam sediaan farmasi dan digunakan untuk keperluan kebersihan, seperti mencuci tangan, badan, pakaian, peralatan, dan lainnya. Sabun terbuat dari campuran asam lemak dan garam alkali yang menimbulkan reaksi saponifikasi atau penyabunan (Zulkifli, M. \& Estiasih, 2014). Molekul sabun terdiri dari bagian hidrofilik yang mudah terikat dengan air dan bagian hidrofobik yang menghindari air, tapi mudah terikat dengan minyak atau lemak. Virus SARS-CoV-2 merupakan patogen yang diselubungi oleh membran lipid (Jaipreet \& Anu Bansal, 2020), dimana membran lipid tersebut dapat larut dan hancur jika dibersihkan dengan sabun.

Panti Asuhan Assalam dan Al-Ikhwan yang berada di Kota Manado merupakan lembaga sosial nirlaba yang menampung, memelihara dan mendidik anak-anak yatim piatu, anak yatim dan anak terlantar. Panti asuhan Assalam dan AlIkhwan masing-masing menampung sekitar 50-
60 anak asuh. Biaya operasional panti asuhan sebagian besar berasal dari sumbangan para donatur. Dengan adanya pandemi COVID-19, membuat para donatur mulai membatasi sumbangan yang diberikan. Berdasarkan hasil wawancara singkat dengan pengurus panti asuhan, pihak panti asuhan mengatakan bahwa sumbangan dari para donatur selama masa pandemi mengalami penurunan dibandingkan dengan masa sebelum pandemi. Kedua panti asuhan tersebut juga belum memiliki sumber lain yang dapat meningkatkan pendapatannya.

Selain itu, banyaknya anak-anak di panti asuhan juga mengharuskan para pengasuh untuk meningkatkan pengawasan terhadap penerapan protokol kesehatan di lingkungan panti asuhan. Walaupun demikian, jumlah anak-anak yang banyak menjadikan panti asuhan memiliki potensi sumber daya manusia yang dapat diberdayakan untuk membantu meningkatkan produktivitas ekonomi di panti asuhan. Akan tetapi, anak-anak tersebut belum pernah diberikan pelatihan yang dapat menjadi keterampilan untuk meningkatkan kesejahteraan panti asuhan.

Oleh karena itu, untuk membantu panti asuhan menjadi lebih mandiri dalam perekonomiannya, serta mendorong penerapan protokol kesehatan di lingkungan panti asuhan, maka tim pengabdian kepada masyarakat dari Fakultas Matematika Dan Ilmu Pengetahuan Alam Universitas Sam Ratulangi melaksanakan edukasi dan pelatihan pembuatan sabun cair antiseptik. Kegiatan ini diharapkan dapat memberdayakan anak-anak di panti asuhan untuk meningkatkan produktivitas ekonomi, serta dapat menjadi upaya pencegahan penularan COVID-19.

\section{Tujuan dan Manfaat Kegiatan}

Kegiatan pengabdian kepada masyarakat ini bertujuan untuk memberikan pengetahuan dan keterampilan kepada anak-anak di panti asuhan mengenai pembuatan sabun cair antiseptik dan mengedukasi penghuni panti asuhan mengenai pentingnya penerapan 
protokol kesehatan dalam mencegah penularan COVID-19.

Manfaat kegiatan ini dapat dirasakan terutama oleh panti asuhan Assalam dan AlIkhwan yang menjadi sasaran utama dalam kegiatan pengabdian kepada masyarakat. Jika panti asuhan tersebut dapat mengimplementasikan pengetahuan dan keterampilan yang telah disampaikan, maka panti asuhan dapat menjadi lebih produktif dan produk sabun cair antiseptik yang dihasilkan dapat digunakan di lingkungan panti asuhan, atau dapat dijual kepada masyarakat umum. Hal ini dapat menghemat pengeluaran panti asuhan untuk pembelian sabun dengan harga yang mahal, juga menjadikan panti asuhan lebih mandiri secara ekonomi serta mendorong terciptanya kebiasaan cuci tangan dengan sabun, sehingga dapat mencegah penularan COVID-19.

Kegiatan ini diharapkan dapat berkontribusi dalam meningkatkan pengetahuan dan keterampilan anak-anak mengenai bahan pembersih berupa sabun dan pentingnya menjaga kebersihan diri agar terhindar dari penyakit menular, terutama penyakit COVID19. Dengan demikian, kegiatan ini mendukung program pemerintah dalam pencegahan COVID-19 melalui penyediaan bahan pembersih untuk cuci tangan, sehingga dapat mendorong penerapan protokol kesehatan dan terbentuknya pola hidup bersih dan sehat dengan budaya cuci tangan.

\section{METODE PELAKSANAAN}

\section{Sasaran kegiatan}

Sasaran dalam pelaksanaan kegiatan pengabdian kepada masyarakat ini yaitu anakanak yang berusia sekitar 10-15 tahun dan pengasuh yang tinggal di Panti Asuhan Assalam dan Panti Asuhan Al-Ikhwan Kota Manado. Tim pengabdian melakukan survey awal ke lokasi yang menjadi sasaran kegiatan, sehingga diperoleh jumlah anakanak dan pengasuh yang akan menjadi peserta dalam kegiatan pengabdian ini, yaitu panti asuhan assalam sekitar 50 orang dan panti asuhan Al-Ikhwan sekitar 40 orang.

\section{Lokasi kegiatan}

Lokasi yang dipilih sebagai tempat pelaksanaan kegiatan pengabdian ini bertempat di lokasi mitra yang menjadi sasaran kegiatan, yaitu di Panti Asuhan Assalam yang terletak di Jl. Pogidon, Mahawu Lingkungan IV, Kelurahan Bailang, Kecamatan Bunaken, Kota Manado dan Panti Asuhan Al-Ikhwan yang terletak di Lingkungan V, Kelurahan Kairagi Satu, Kecamatan Mapanget, Kota Manado. Pemilihan lokasi kegiatan dengan mempertimbangkan ketersediaan ruangan pertemuan serta jumlah peserta yang terlibat dalam kegiatan ini. Kegiatan pengabdian dilaksanakan pada bulan September 2021 dengan menerapkan protokol kesehatan selama pandemi COVID-19.

\section{Metode yang digunakan :}

Kegiatan pengabdian kepada masyarakat ini dilaksanakan dengan pendekatan metode patisipasi aktif dari mitra, yang terdiri dari beberapa tahapan, sebagai berikut:

1. Tahap Koordinasi

Tim melakukan koordinasi dengan mitra terkait yaitu, pengurus panti asuhan Assalam dan Al-Ikhwan mengenai pelaksanaan kegiatan pengabdian, sehingga mitra dapat menyediakan waktu dan tempat untuk pelaksanaan kegiatan di lokasi mitra.

2. Persiapan Kegiatan

Tim melakukan persiapan dengan menyiapkan materi penyuluhan yang menarik, materi edukasi tentang sabun, juga menyiapkan alat dan bahan yang akan digunakan selama kegiatan berlangsung.

3. Pelaksanaan Penyuluhan

Penyuluhan akan dilaksanakan dengan memberikan materi COVID-19, pola hidup bersih dan sehat, serta penerapan protokol kesehatan. Penyuluhan ini disampaikan dalam bentuk ceramah dan tanya jawab kepada peserta.

4. Pelatihan Pembuatan Sabun Cair Antiseptik 
Pelatihan pembuatan sabun cair antiseptik terdiri dari 3 tahapan, dimana tahapan pertama yaitu pemberian edukasi mengenai sabun, tahap kedua dengan praktek pembuatan sabun cair antiseptik hingga pengemasannya, dan tahap ketiga dengan mempraktekkan cara cuci tangan yang benar menggunakan produk sabun cair antiseptik yang dihasilkan.

5. Evaluasi

Evaluasi akan dilakukan untuk menilai dan menyimpulkan kesesuaian kegiatan yang berlangsung terhadap rencana awal kegiatan. Umpan balik yang diberikan mitra melalui tanya jawab dan antusiasme peserta selama kegiatan, serta produk sabun cair antiseptik yang dihasilkan akan menjadi alat ukur keberhasilan kegiatan ini.

\section{HASIL DAN PEMBAHASAN}

Program Kemitraan Masyarakat (PKM) merupakan salah satu kegiatan yang dikembangkan oleh Lembaga Penelitian dan Pengabdian kepada Masyarakat (LPPM) Universitas Sam Ratulangi sebagai upaya untuk memecahkan permasalahan yang ditemukan di masyarakat melalui pendekatan ilmu pengetahuan dan teknologi. Tim pengabdian dari Fakultas Matematika dan Ilmu Pengetahuan Alam Universitas Sam Ratulangi telah melaksanakan kegiatan edukasi dan pelatihan pembuatan sabun cair antiseptik di lokasi masing-masing mitra sasaran, yaitu di Panti Asuhan Assalam dan Panti Asuhan Al-Ikhwan sesuai dengan tahapan yang sudah direncanakan sebelumnya.

\section{Tahap Koordinasi}

Tim pengabdian melakukan observasi ke lokasi mitra sasaran yaitu Panti Asuhan Assalam dan Panti Asuhan Al-Ikhwan untuk melihat keadaan dan lingkungan tempat tinggal mitra, terutama yang terkait dengan pola hidup serta penerapan protokol kesehatan. Selanjutnya, tim pengabdian melakukan diskusi dan wawancara singkat terhadap ketua dari masing-masing panti asuhan tersebut untuk melaksanakan kegiatan pengabdian yang diharapkan dapat menjadi solusi atas permasalahan yang dihadapi oleh mitra sasaran. Kedua mitra sasaran sangat tertarik dengan kegiatan pengabdian yang ditawarkan, yang kemudian berlanjut ke tahap koordinasi untuk merencanakan pelaksanaan kegiatan pengabdian ini. Masing-masing mitra sasaran bersedia menyediakan tempat dan waktu untuk pelaksanaan kegiatan ini, yang disepakati pada hari sabtu atau minggu dengan mempertimbangkan waktu tersebut sebagai hari libur dari kegiatan sekolah.

\section{Persiapan Kegiatan}

Persiapan yang dilakukan oleh tim pengabdian meliputi materi penyuluhan tentang COVID-19, pola hidup bersih dan sehat, serta penerapan protokol kesehatan, materi edukasi tentang sabun, serta bahan-bahan dan peralatan yang dibutuhkan untuk pelatihan pembuatan sabun cair antiseptik. Tim juga mempersiapkan perlengkapan yang dibutuhkan agar protokol kesehatan tetap diterapkan selama kegiatan berlangsung. Di tahap ini juga, tim melakukan koordinasi lebih lanjut dengan ketua dari masing-masing mitra sasaran mengenai jadwal kegiatan dan susunan acara dari kegiatan pengabdian ini. Selanjutnya disepakati untuk waktu pelaksanaan kegiatan pengabdian di Panti Asuhan Al Ikhwan pada 11 September 2021 dan di Panti Asuhan Assalam pada 19 September 2021.

\section{Pelaksanaan Penyuluhan}

Kegiatan pengabdian kepada masyarakat diawali dengan pengkondisian peserta agar menerapkan protokol kesehatan yaitu menggunakan masker selama kegiatan berlangsung dan menjaga jarak. Selanjutnya, kegiatan dimulai dengan acara pembukaan, penyampaian sambutan-sambutan, kemudian dilanjutkan dengan pelaksanaan penyuluhan mengenai COVID-19 dan terapinya, pola hidup bersih dan sehat, serta penerapan protokol kesehatan. Tujuan penyuluhan ini untuk memberikan ilmu dan pemahaman kepada 
JPAI

Jurnal Perempuan dan Anak Indonesia penghuni panti asuhan mengenai COVID-19 dan terapinya serta pentingnya penerapan protokol kesehatan untuk mencegah penularan COVID-19. Penyuluhan ini diharapkan dapat memunculkan kesadaran dari para penghuni panti asuhan untuk menerapkan protokol kesehatan di lingkungan panti asuhan. Penyuluhan ini disampaikan oleh narasumber Apoteker dalam bentuk ceramah dan tanya jawab kepada peserta untuk menilai pemahaman terhadap materi yang telah disampaikan.

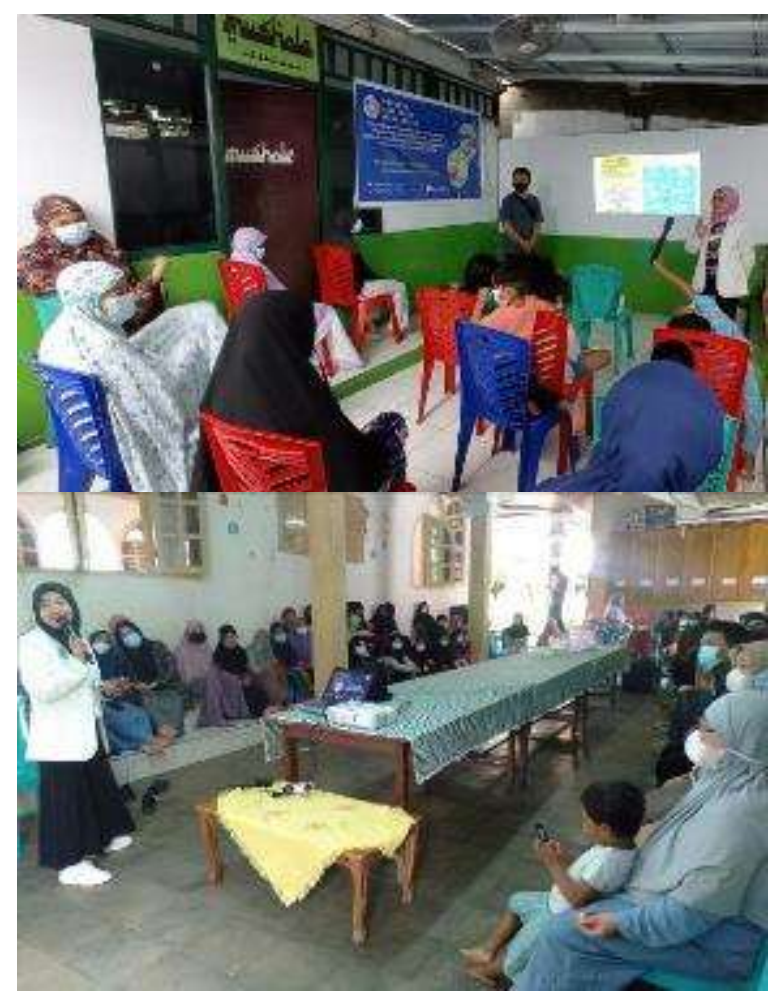

Gambar 1. Kegiatan Penyuluhan oleh

Narasumber Apoteker

\section{Pelatihan Pembuatan Sabun Cair Antiseptik}

Kegiatan dilanjutkan dengan pelatihan pembuatan sabun cair antiseptik, yang diawali dengan pemberian edukasi tentang sabun yang mencakup definisi dan penggunaan sabun, prinsip pembuatan sabun, bahan-bahan yang digunakan untuk menghasilkan sabun, alat-alat yang diperlukan dalam pembuatan sabun, cara pengemasan sabun yang baik, serta strategi pemasaran produk sabun yang dihasilkan.

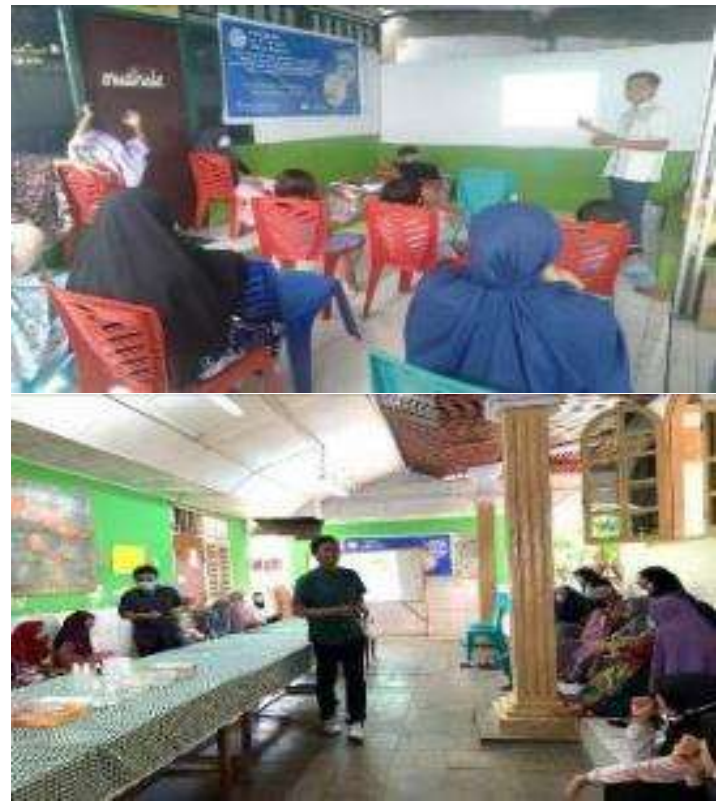

Gambar 2. Pemberian Edukasi tentang Sabun oleh Tim Pengabdian

Kemudian, dilakukan bimbingan teknis kepada peserta untuk mempraktekan pembuatan sabun cair antiseptik hingga pengemasannya. Tim mempersiapkan bahan-bahan dan peralatan yang akan digunakan untuk pembuatan sabun, dengan bahan yang terdiri dari sodium lauryl sulphate (SLS), cocamidopropyl betaine, lauramine oxide, glycerin, citric acid, natrium chloride, benzalkonium chloride (BKC), pewangi, pewarna dan aquadest. Peralatan yang digunakan yaitu, timbangan, sarung tangan, wadah untuk pencampuran bahan, pengaduk, gelas ukur, kertas indikator $\mathrm{pH}$, corong, wadah kemasan berupa botol pompa atau pouch.

Sebelum memulai praktek pembuatan sabun cair, peserta diwajibkan menggunakan alat pelindung diri (APD) berupa sarung tangan karet dan masker. Hal ini dikarenakan, beberapa bahan (belum diencerkan atau dilarutkan) yang digunakan untuk pembuatan sabun dapat menimbulkan iritasi jika kontak langsung dengan kulit. 


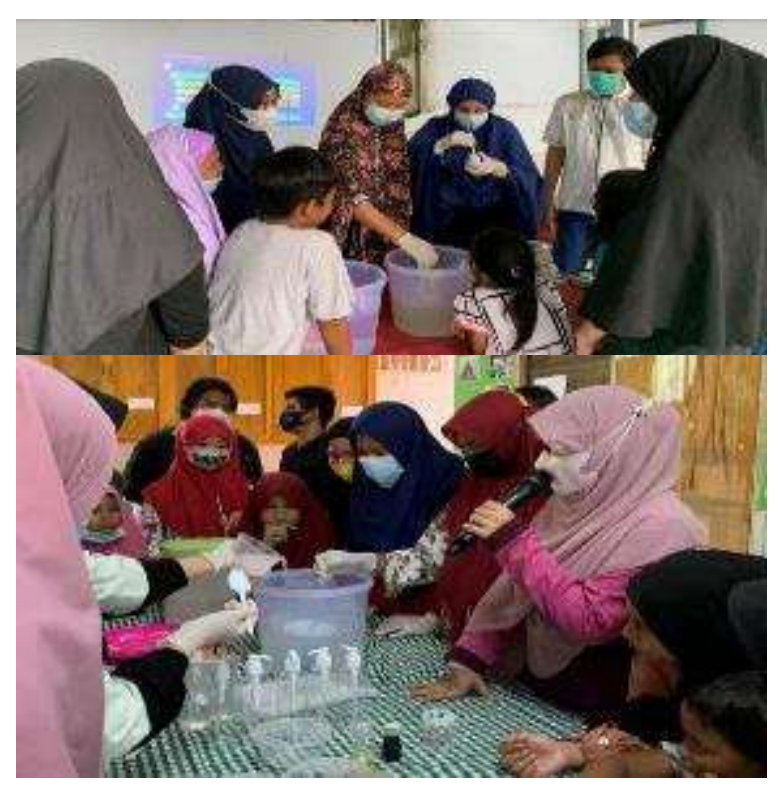

Gambar 3. Praktek Pembuatan Sabun Cair

Antiseptik oleh Anak-Anak Panti Asuhan dengan Bimbingan dari Tim Pengabdian

Prosedur pembuatan sabun cair antiseptik dimulai dengan menimbang bahan-bahan yang akan digunakan. Kemudian, SLS dilarutkan ke dalam aquadest sambil diaduk perlahan-lahan. Proses melarutkan SLS membutuhkan waktu yang cukup lama. Selanjutnya, cocamidopropyl betaine, lauramine oxide, dan glycerin dimasukkan ke dalam larutan SLS secara perlahan-lahan sambil diaduk hingga tercampur. Citric acid dan natrium chloride, masing-masing harus dilarutkan terlebih dahulu ke dalam sebagian aquadest, kemudian dimasukan ke dalam larutan SLS dan diaduk hingga tercampur. Selanjutnya, BKC dan sisa aquadest dimasukkan ke dalam campuran bahan, aduk perlahan-lahan hingga tercampur. Pada tahap ini, perlu dilakukan pengecekan $\mathrm{pH}$ menggunakan kertas indikator agar dapat diketahui bahwa $\mathrm{pH}$ sabun cair yang dibuat sudah sesuai dengan $\mathrm{pH}$ kulit. $\mathrm{pH}$ sabun cair yang dihasilkan menunjukkan angka 5, dimana $\mathrm{pH}$ tersebut sudah sesuai dengan $\mathrm{pH}$ kulit normal (4-6), sehingga sabun yang dihasilkan cukup aman digunakan untuk mencuci tangan. Selanjutnya, tambahkan pewangi dan pewarna secukupnya ke dalam sediaan sabun cair agar bau dan penampilan sabun menjadi lebih menarik.
Setelah produk selesai dibuat, tim mengajak peserta untuk mempraktekkan cara cuci tangan yang benar dengan menggunakan produk sabun cair antiseptik yang dihasilkan. Tim juga menempelkan poster cara cuci tangan yang tepat di sekitaran panti asuhan untuk memudahkan penghuni panti asuhan membaca dan menerapkannya.

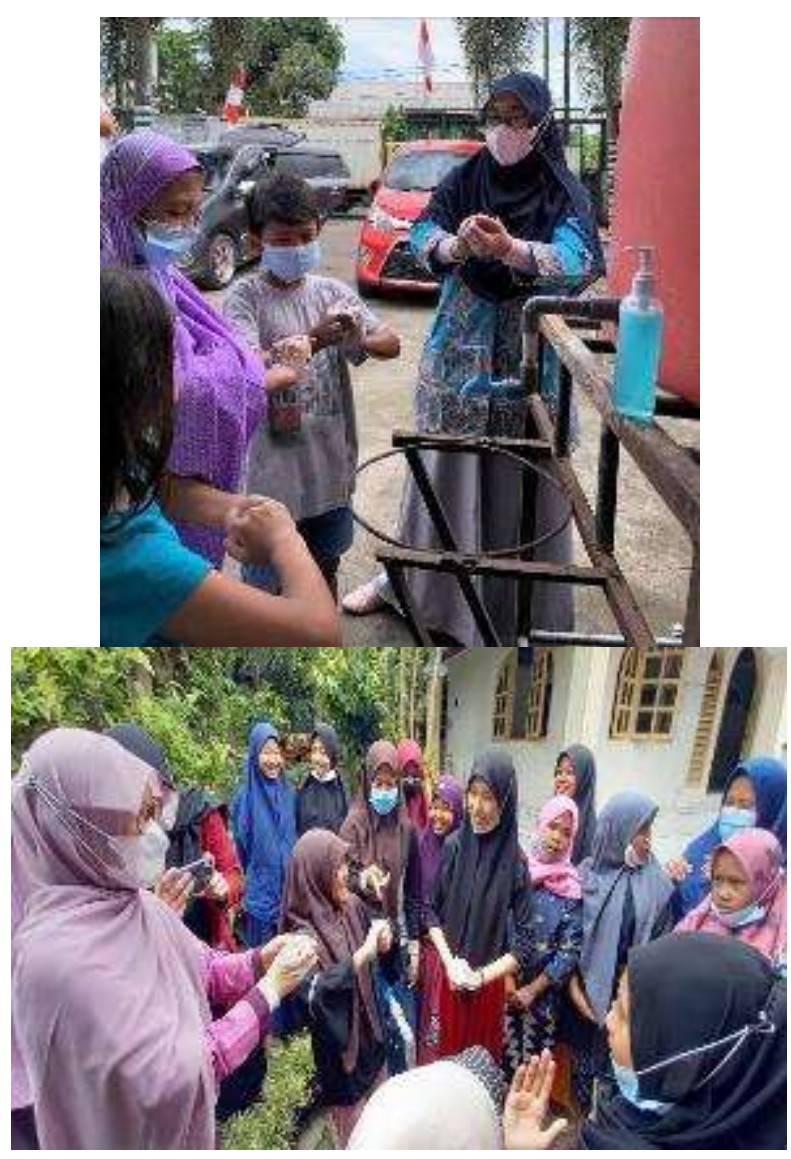

Gambar 4. Praktek Cara Mencuci Tangan yang Benar oleh Tim Pengabdian

\section{Evaluasi}

Evaluasi dilakukan selama kegiatan berlangsung dengan memperhatikan keaktifan peserta untuk terlibat dalam kegiatan pengabdian ini, dimana peserta aktif menjawab pertanyaanpertanyaan yang diajukan narasumber dan sangat antusias saat praktek pembuatan sabun yang terlihat dari pertanyaan-pertanyaan yang diajukan peserta selama proses pembuatan sabun. Peserta juga mampu membuat dan menghasilkan sabun cair antiseptik yang cukup aman untuk digunakan mencuci tangan. Sabun cair tersebut 
memiliki warna yang menarik, konsistensi yang agak kental, bau yang wangi, menghasilkan busa yang banyak, tidak mengiritasi kulit dan menimbulkan kesan lembut dan lembab setelah penggunaannya.

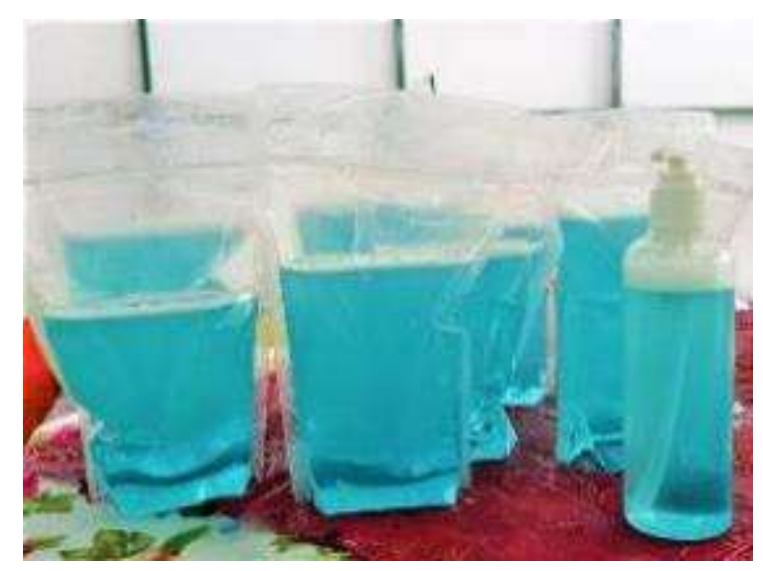

Gambar 5. Produk Sabun Cair Antiseptik yang dihasilkan oleh Anak-Anak Panti Asuhan

\section{KESIMPULAN DAN SARAN}

Kegiatan pengabdian kepada masyarakat dengan pemberdayaan anak-anak di panti asuhan Assalam dan Al-Ikhwan melalui edukasi dan pelatihan pembuatan sabun cair antiseptik telah dilaksanakan. Saat ini, anak-anak di panti asuhan telah memiliki pengetahuan dan keterampilan pembuatan sabun cair antiseptik, baik proses pembuatan, pengemasan, hingga pemasarannya. Para penghuni panti asuhan juga sudah mengetahui mengenai bahaya COVID-19 serta protokol-protokol kesehatan yang dapat mencegah penularan COVID-19, salah satunya mencuci tangan dengan sabun.

\section{UCAPAN TERIMAKASIH}

Ucapan terima kasih disampaikan kepada Lembaga Penelitian dan Pengabdian kepada Masyarakat (LPPM) Universitas Sam Ratulangi atas didanainya kegiatan ini melalui skema Hibah Dana PNBP Universitas Sam Ratulangi Tahun 2021. Tim pengabdian juga mengucapkan terima kasih kepada Ketua, pengurus, pengasuh serta anak-anak dari Panti Asuhan Assalam dan Al Ikhwan atas kebersediaan dan kesempatan yang diberikan untuk mengadakan kegiatan pengabdian kepada masyarakat di tempat tersebut.

\section{DAFTAR PUSTAKA}

Anonim. 2020. Panduan Cuci Tangan Pakai Sabun. Kementerian Kesehatan Republik Indonesia.

https://kesmas.kemkes.go.id/assets/upload /dir_519d41d8cd98f00/files/Panduan_CT PS2020_1636.pdf (akses 5 Februari 2021)

Jaipreet and Bansal, A. 2020. Coronavirus: A Review. European Journal of Molecular \& Clinical Medicine. 7 (7):5927-5934

Satgas Penanganan COVID-19. 2021. Data Sebaran COVID-19 di Indonesia. https://covid19.go.id/ (akses 5 Februari 2021)

World Health Organization. Coronavirus disease (COVID-19). https://www.who.int/healthtopics/coronavirus\#tab=tab_3 (akses 5 Februari 2021)

Z.A., Safrizal, dkk. 2020. Pedoman Umum Menghadapi Pandemi COVID-19 bagi Pemerintah Daerah: Pencegahan, Pengendalian, Diagnosis dan Manajemen. Tim Kerja Kementerian dalam Negeri. https://covid19.go.id/p/panduan/kemenda gripedoman-umum-menghadapi-pandemicovid-19-bagi-pemerintah-daerah (akses 5 Februari 2021)

Zulkifli, M. dan Estiasih. 2014. Sabun dari Distilat Asam Lemak Minyak Sawit. Jurnal Pangan dan Agroindustri. 2 (4): 170177.

https://jpa.ub.ac.id/index.php/jpa/article/vi ew/89/107 (akses 5 Februari 2021) 